\title{
The Development and Application of ELISA for 3-Indole-Butyric Acid
}

Eline P Meulenberg*

ELTI Support VOF, Ambachtsweg 5, 6581 AX Malden, The Netherlands

\begin{abstract}
Indole-3-butyric acid (IBA) is a plant growth hormone used to improve the formation of roots during the culture of cuttings in the greenhouse. According to new EC regulations, IBA levels should approach zero at the time the plantlets are entering the market (30 days). In order to be able to measure IBA in soil samples, polyclonal antibodies and corresponding ELISA was developed. Both chicken ( $\lg Y)$ and rabbit $(\mathrm{IgG})$ were raised and used to evaluate direct and indirect ELISAs. It appeared that rabbit antibody in the indirect ELISA showed the best performance. Due to matrix effects, the standard curve was made in blank soil extract in a range of $0-500 \mu \mathrm{g} / \mathrm{mL}$. The detection limit at 3SD from zero standard varied from $0.35-3.1 \mu \mathrm{g} / \mathrm{mL}$. The antibody was highly specific for IBA and showed a mean recovery of $74.5 \%$ after two consecutive extraction steps of spiked blank samples. This ELISA was used to monitor IBA in cutting soils extracts from 0-30 days after application (Day 0-1-3-8-30). It appeared that at day 8 IBA was already undetectable. The results were confirmed with HPLC. It may be concluded that the ELISA for IBA developed was suitable to analyze IBA in soil samples and that plantlets in cutting soil treated with IBA are allowed to market according to $\mathrm{EC}$ regulations.
\end{abstract}

Keywords: Indole-3-butyric acid; ELISA; Immunization; Immunoassay

\section{Introduction}

3-Indole-butyric acid (IBA) is a member of the family of plant growth hormones. Synthetic IBA is used for the treatment of cuttings to accelerate the formation of roots during the cultivation in the greenhouse. Before bringing plants to the market, the medium (soil) has to be assessed to be free of IBA, according to EU regulations. However, the fate of IBA in the growth substrate after treatment and planting of the cuttings is not sufficiently established. An HPLC method for the analysis of IBA in soil samples was established (TNO Triskelion, Zeist, Netherlands). However, this conventional method is laborious and expensive. An alternative method for the analysis of small compounds such as IBA, in a complex environment is the ELISA, which is based on the specific and high-affinity binding of the target compound to a cognate antibody. The principle of immunoassay has been described in handbooks, manuals and various publications [1-5]. The design of ELISAs and the different formats, including advantages and disadvantages, is included. For an ELISA to be generally accepted, it has to meet the conditions of the ISO norm 15089. To this end, the particular ELISA should be validated based on the parameters mentioned in this ISO norm.

Antibodies against IBA are not commercially available and for that reason in this project they were raised both in rabbits and chicken. For polyclonal antibodies, rabbits are the most commonly used experimental animals. However, in our experience, for small target compounds chicken may sometimes lead to good results when not obtained in rabbits. To this end, immunogen (IBA-BSA) and tracer (IBA-HRP) were synthesized. The best performing antibodies in a checker-board design were used to investigate the design and performance of ELISA in two formats, the direct competitive ELISA (dcELISA) and the indirect competitive ELISA (icELISA). As the icELISA showed the most promising performance, it was validated. Using this indirect ELISA, cutting media samples were then analysed for the presence and concentration of IBA.

\section{Materials and Methods \\ Materials}

Buffer: PBS (phosphate-buffered saline, $0.01 \mathrm{M}, \mathrm{pH}$ 7.4); PBS-T (wash buffer, PBS+0.05\% Tween 20); PBS-Marvel (blocking buffer, PBS+1\% Marvel (skimmed milk powder)); PBS-BSA (PBS+0.1\% BSA (bovine serum albumin)); Carbonate buffer (coating buffer, $0.05 \mathrm{M}$ $\mathrm{Na}_{2} \mathrm{CO}_{3}, \mathrm{pH}$ 9.6); TMB (colour solution, $100 \%$ solution $\mathrm{A}+1 \%$ solution $\mathrm{B}+1 \%$ solution $\mathrm{C})$; Solution A $\left(50 \mathrm{mM} \mathrm{Na} \mathrm{HPO}_{4} \cdot 2 \mathrm{H}_{2} \mathrm{O}, \mathrm{pH} 5.0\right.$ (adjusted with concentrated citric acid)); Solution B (10 mg/ml TMB in DMSO (TMB=tetramethylbenzidine)); Solution $\mathrm{C}=1.25 \%$ urea in water; Stop solution $=0.1 \mathrm{~N} \mathrm{HCl}$. Extraction buffer $(10 \% \mathrm{MeOH}$ in demineralised water).

Immune reagents: IBA-BSA=immunogen; IBA-HRP=tracer; IBA-OVA=coating conjugate. These conjugates were synthesized by Analytic Devices (Zeist, the Netherlands). Anti-IBS IgY=chicken antibody; anti-IBA IgG=rabbit antibody. These were produced and purified by ThermoScientific (Etten-Leur, The Netherlands). Rabbitanti-IgY-HRP=antibody against IgY raised in rabbit and conjugated to HRP (Sigma-Aldrich, Zwijndrecht, The Netherlands). Goat-anti-IgG$\mathrm{HRP}=$ antibody against rabbit-IgG raised in goat and conjugated to HRP; purchased from Sigma-Aldrich (Zwijndrecht, The Netherlands).

Further materials: Methanol, HPLC grade; ethanol, HPLC grade; 3 -indole butyric acid (IBA) (100\% pure, provided by Rhizopon, Alphen an den Rijn, The Netherlands); indole-acetic acid (IAA) (Sigma, Zwijndrecht, the Netherlands); 1-naphtaleneacetic acid (NAA) (Sigma,

*Corresponding author: Eline P. Meulenberg, ELTI Support VOF, Ambachtsweg 5, 6581 AX Malden, The Netherlands, Tel: +31 616503626; E-mail: E.Meulenberg@eltisupport.nl

Received October 13, 2015; Accepted October 26, 2015; Published October 30 2015

Citation: Meulenberg EP (2015) The Development and Application of ELISA for 3-Indole-Butyric Acid. Immunochem Immunopathol 1: 104. doi: 10.4172/24699756.1000104

Copyright: $\odot 2015$ Meulenberg EP. This is an open-access article distributed under the terms of the Creative Commons Attribution License, which permits unrestricted use, distribution, and reproduction in any medium, provided the original author and source are credited. 
Citation: Meulenberg EP (2015) The Development and Application of ELISA for 3-Indole-Butyric Acid. Immunochem Immunopathol 1: 104. doi: 10.4172/2469-9756.1000104

Page 2 of 7

Zwijndrecht, the Netherlands); 6-benzylaminopurine (NBA) (Sigma); IBA $2 \%$ powder in talk (Rhizopon). Microtiter plates, middle and highbinding, 96 wells (Costar, Greiner; purchased from Sigma-Aldrich, Zwijndrecht, the Netherlands). Filter units $(0.45 \mu \mathrm{m}, 30 \mathrm{~mm}$; Carl Roth, Karlsruhe, Germany). Polypropylene reaction tubes $(10 \mathrm{ml}$; Van den Brink, Lienden, the Netherlands). Dry standard cutting medium free from IBA (Horticoop, obtained through Cultus Agro Advies, Lottum NL). Fresh cutting medium from Blgg Agro Xpertus (Naaldwijk NL). Used cutting medium (Treated with Rhizopon AA powder $1 \%$ from Blgg Agro Xpertus (Naaldwijk).

Samples: Cutting medium samples in trays with culture cups containing plantlets. Half of the samples were untreated (blanks) and half of the samples were treated with Rhizopon AA powder $2 \%$. The trays delivered were sampled at day 0 , day 1 , day 3 , day 8 and day 30 . The samples were extracted immediately, except those of day 30 , which were stored at $-20^{\circ} \mathrm{C}$ for 5 days prior to extraction. Extracts were stored at $-20^{\circ} \mathrm{C}$ until analysis (less than one month).

Equipment: Eppendorf Centrifuge (Eppendorf, Hamburg, Germany); Microtiter platereader Spectramax M5 (Molecular Devices, Berkshire, UK).

\section{Methods}

Synthesis of conjugates: The following three conjugates were synthesized: IBA-OVA=coating conjugate; IBA-BSA=immunogen; IBA-HRP=enzyme tracer. For the synthesis of the conjugates three carrier proteins were used: Ovalbumin (OVA), Bovine Serum Albumin (BSA), Horse Radish Peroxide (HRP). To these carrier proteins IBA (MW 203) was conjugated using the 'mixed anhydride' method.

Mixed anhydride method: Dissolve $12.6 \mathrm{mg}$ of IBA $(62 \mu \mathrm{mol})$ in $1 \mathrm{ml}$ of DMF and subsequently add $18 \mu \mathrm{l}$ of tributylamine and $10 \mu \mathrm{l}$ of isobutylchloroformate: stir for 1 hour at R.T. in a sealed vial. Then dilute the mixture with $1.8 \mathrm{ml}$ of DMF (Total volume $=2.8 \mathrm{ml}$; mixture a). Separately dissolve $166 \mathrm{mg}$ of carrier protein in $41 \mathrm{ml}$ of borate buffer (mixture b). Slowly add $1000 \mu \mathrm{l}$ of the above mixture on ice water to 15 $\mathrm{ml}$ of mixture b. Then stir for another 2 hours in a sealed vial at R.T.

Purification: The conjugates were purified and isolated using Biorad Econo-Pac 10DG columns with HSB as mobile phase according to the recommendation of the manufacturer. Yield was $4 \mathrm{ml}$ and the concentration was $2.8 \mathrm{mg}$ protein $/ \mathrm{ml}$.

Immunizations: Using IBA-BSA, immunizations were performed in 2 rabbits and 2 chickens. The immunizations were executed by Thermo Fisher Scientific (Waltham, US). The reason to choose two different animal species was to enhance the success rate. The conjugate IBA-BSA was administered to the animals in an amount of $100 \mu \mathrm{g}$ in 0.5 $\mathrm{ml}$ of Complete Freunds Adjuvant (CFA). Booster immunizations were administered in an amount of $100 \mu \mathrm{g}$ in $0.5 \mathrm{ml}$ of Incomplete Freunds Adjuvant (IFA). The immunization schema is given below. During the immunization period the titer of the antibody was monitored by Thermo Fisher Scientific using the icELISA and the crude immune serum in several dilutions. The immunization scheme is shown in Table 1. The titer of the antibodies evolved as shown in Table 2. It was decided that the titers of the chickens and rabbits were sufficiently high for usage and therefore the final egg samples and the serum were collected for purification of $\operatorname{IgY}$ and $\operatorname{IgG}$, respectively.

\begin{tabular}{|c|c|c|}
\hline \multicolumn{3}{|c|}{ Chickens PU0158 and PU0159 } \\
\hline Day & Activity & Description \\
\hline 0 & Blood sampling & Pre-Bleed \\
\hline 0 & Injection & First Inoculation \\
\hline 5 & Analysis & \\
\hline 14 & Injection & Booster \\
\hline 21 & Eggs & Collection of eggs \\
\hline 42 & Injection & Booster \\
\hline 48 & Eggs & Collection of eggs \\
\hline 56 & Plasmapheresis & Testing of Blood \\
\hline 61 & Analysis & Collection of blood and eggs, purification of $\lg Y$ \\
\hline \multicolumn{3}{|c|}{ Rabbits PA5207 and PA5208 } \\
\hline Day & Activity & Description \\
\hline 0 & Blood sampling & Pre-Bleed \\
\hline 0 & Injection & First Inoculation \\
\hline 5 & Analysis & \\
\hline 14 & Injection & Booster \\
\hline 28 & Blood sampling & Production of blood \\
\hline 33 & Analysis & \\
\hline 42 & Injection & Booster \\
\hline 56 & Injection & Booster \\
\hline 56 & Blood sampling & Production of blood \\
\hline 61 & Analysis & \\
\hline 70 & Blood sampling & Production of blood \\
\hline 72 & Blood sampling & Production of bleed \\
\hline 75 & Analysis & Collection of blood, purification of IgG \\
\hline
\end{tabular}

Table 1: Immunization scheme for chickens and rabbits. Shown is the scheme for the immunizations of chickens and rabbits for the production of antibodies against IBA.

\section{Characterization of antibodies}

Checkerboard: In order to assess the optimal concentration of the antibodies in combination with either the optimal concentration of tracer conjugate (IBA-HRP) in the dcELISA or of coating conjugate (IBA-OVA) in the icELISA using our in-house ELISA and immune reagents, a so-called checkerboard assay was designed.

Direct immunoassay: Microtiter plates (Costar, high-binding) were coated with antibody $(200 \mu \mathrm{l})$ in serial dilutions from $200-25600$ times in carbonate buffer, $\mathrm{pH}$ 9.6. After overnight incubation at $4^{\circ} \mathrm{C}$ the plates were washed 3 times under flowing tap water. Then $200 \mu$ lof serial 200-6400 fold dilutions of IBA-HRP in PBS pH 7.4 were added. After overnight incubation at $4^{\circ} \mathrm{C}$ the plates were washed again 3 times under flowing tap water. $100 \mu \mathrm{l}$ of TMB was added and after the appropriate time period for colour development (15-45 min.) the enzyme reaction was stopped by adding $50 \mu \mathrm{l}$ of stop solution. The plates were read in a microtiter platereader (SpectraMax M5) at $450 \mathrm{~nm}$. The results were evaluated for the titer of the respective antibodies (at 50\% of maximum binding) and the optimal amount of tracer (absorption between 1.5 and 2.0 units).

Indirect assay: Microtiter plates (Costar, high-binding) were coated with serial 200-6400-fold dilutions of IBA-OVA in carbonate buffer, $\mathrm{pH}$ 9.6. After overnight incubation at $4^{\circ} \mathrm{C}$ the plates were washed 3 times under flowing tap water. Then $200 \mu \mathrm{l}$ of blocking solution was added, followed by 2 hours incubation at room temperature and washing. Subsequently, $200 \mu \mathrm{l}$ of serial 200-25600 fold dilutions of antibody in PBS-BSA was added, followed by overnight incubation at $4^{\circ} \mathrm{C}$. After washing 3 times under flowing tap water, $100 \mu \mathrm{l}$ of antichicken-HRP in PBS was added in the dilution recommended by the manufacturer, followed by 2 hours incubation at room temperature. 


\begin{tabular}{|c|c|c|}
\hline Animal code & Time & Titer \\
\hline \multirow{2}{*}{ PU0158 } & Pre-bleed & $<50$ \\
\hline \multirow{2}{*}{ PU0159 } & Day 50 & 3200 \\
\hline \multirow{2}{*}{ PA207 } & Pre-bleed & $<50$ \\
\hline \multirow{2}{*}{} & Day 50 & 1600 \\
\hline \multirow{3}{*}{ PA208 } & Pre-bleed & $<50$ \\
\hline \multirow{2}{*}{} & Day 28 & 25600 \\
\hline & Day 56 & 102400 \\
\hline & Day 72 & $>204800$ \\
\hline & Pre-bleed & $<50$ \\
\hline & Day 28 & 51200 \\
\hline & Day 56 & $>204800$ \\
\cline { 2 - 3 } & Day 72 & $>204800$ \\
\hline
\end{tabular}

Table 2: Titer of antibodies in the experimental animals. Shown is the course of antibody evolution as the titer of the respective antibodies in the experimental animals.

Then, after 3 times washing, $100 \mu \mathrm{l}$ of TMB was added and the colour reaction was performed for 15 minutes at R.T. The enzyme reaction was stopped with $50 \mu \mathrm{l}$ of stop solution. Measurement and analysis of the results were the same as in the direct assay.

\section{Assay validation}

Standard curve: For the construction of a standard curve a stock solution of IBA of $20 \mathrm{mg} / \mathrm{ml}$ in methanol $(\mathrm{MeOH})$ was prepared and stored at $4^{\circ} \mathrm{C}$. From this stock solution before each assay a fresh series of standard concentration in PBS was prepared, generally 0-1-5-10-50$100-500 \mu \mathrm{g} / \mathrm{ml}$. At higher concentrations, IBA was insoluble in PBS. For the analysis of the extracts, the standard curve was made in blank extract in the same range of concentrations. The standard curve was used to determine the detection limit and the working range using the 4-parameter logit-log transformation. The detection limit was interpolated as the concentration at Standard 0-3x SD. The working range was defined as the concentrations between the lower and higher detection limit.

Cross-reactivity: In order to determine the specificity of the antibody, its cross-reactivity with structurally related compounds was assessed. To this end, a series of dilutions of indole-3-acetic acid (IAA), naphthalene acetic acid (NAA) and 6-benzylaminopurine (BAP) was prepared and measured in the same assay as IBA. BAP appeared to be insoluble in an assay-compatible solvent such as methanol or PBS. The percentage cross-reactivity was calculated as the concentration of compound at $50 \%$ binding/the concentration of IBA at $50 \%$ binding ${ }^{\star} 100 \%$.

Matrix effects: Matrix effects are the effects of unknown substances in sample matrix to be analysed that have an influence on the standard curve. In this case, blank cutting medium samples without any IBA added were treated as described below. Using the extract, a standard curve was constructed in the same way as before and used in the assay together with the standards in PBS. The results are shown in Figure 1B. It was concluded that in this case cutting medium extract has an effect on the standard curve and thus on the calculation of unknown concentrations of IBA in cutting medium samples. Therefore, in the assay of cutting medium samples the standard curve was made in blank cutting medium extract.

Recovery: In order to assess the amount of IBA recovered from cutting medium samples using the extraction method described below, IBA from stock solution was added to five blank cutting medium samples (code S1-S5) in a concentration of 200 or $25 \mu \mathrm{g} / \mathrm{mL}$. These samples were left standing for $24 \mathrm{hrs}$ and then processed as described below.

Linearity: To assess the linearity in the ELISA the blank sample extract code C with $50 \mu \mathrm{l}$ of $20 \mathrm{mg} / \mathrm{ml}$ of IBA added was diluted $2 \mathrm{x}, 4 \mathrm{x}$ and $8 \mathrm{x}$ with blank sample extract, code L1, L2, L3, L4, and analysed in the ELISA.

Cutting medium sample extraction: Samples from the field trial included cutting medium and normal soil, with or without plant cuttings. These samples were received in trays on 11, 12, 14, 19 March and on 10 April 2013. Trays were coded as given in Table 4.

After receipt of the trays, 10 cups ( 6 treated and 4 blank) were randomly selected from the following trays with cutting medium: $4 \mathrm{~B}$ and $12 \mathrm{~B}$ (day 0 ), $16 \mathrm{~B}$ and $24 \mathrm{~B}$ (day 1 ), 28B and $36 \mathrm{~B}$ (day 3 ), 40B and $48 \mathrm{~B}$ (day 8 ) and 52B and 60B (day 30 ). The contents of these cups were submitted to the extraction procedure outlined below. The rest of the trays were stored frozen.

\section{Extraction procedure:}

- Removal of the cutting (treated samples)

- Weighing of the amount of cutting medium in each cup after transfer into $100 \mathrm{ml}$ Erlenmeyers

- Add $15 \mathrm{ml}$ of PBS-10\% $\mathrm{MeOH}$ to the blank samples and $10 \mathrm{ml}$ of PBS- $10 \% \mathrm{MeOH}$ to the treated samples

- Mix and let stand for about 30 minutes

- Press the wetted cutting medium through a tea strainer and collect the aqueous phase in polypropylene (PP) tubes while retaining the extracted medium

- Centrifuge the tubes for 10 minutes at 10,000 rpm (Eppendorf centrifuge)

- Filter the supernatant through filter devices $(0.45 \mu \mathrm{m}, 30 \mathrm{~mm}$ diameter)

- Collect the filtrate in PP tubes and neutralize with 1 or 2 drops of $0.4 \mathrm{~N} \mathrm{NaOH}$ depending on the volume

- Let the tubes stand for about 30 minutes and centrifuge for 10 minutes at $10,000 \mathrm{rpm}$

- Transfer the supernatant into PP tubes

- Repeat the extraction using the retained once extracted medium

- Use both supernatants for separate analysis directly or store at $-20^{\circ} \mathrm{C}$ until analysis.

\section{Results}

\section{Checkerboard}

The results of the checkerboard assays are shown in Table 3. It appeared that the dcELISA was not possible for the chicken antibodies. The highest titer was found in the icELISA using rabbit antibody PA5208. The antibody PA5208 purified by ThermoScientific was used for further development and evaluation of the ELISA. Evaluation was performed according to the ISO norms (ISO 15089) for immunoassays for environmental target compounds. This evaluation includes the assessment of: standard curve, detection limit, working range, matrix effects, cross-reactivity, recovery, linearity, and precision. 
Citation: Meulenberg EP (2015) The Development and Application of ELISA for 3-Indole-Butyric Acid. Immunochem Immunopathol 1: 104. doi: 10.4172/2469-9756.1000104

\begin{tabular}{|c|c|c|}
\hline \multirow{2}{*}{ Animal code } & \multicolumn{2}{|c|}{ Titer } \\
\cline { 2 - 3 } & Direct assay & Indirect assay \\
\hline PU0158 & - & D50 $\pm 12,800$ \\
\hline PU0159 & - & $\mathrm{D} 50 \pm 6,400$ \\
\hline \multirow{2}{*}{ PA5207 } & $\mathrm{D} 56 \pm 10,000$ & $\mathrm{D} 56 \pm 30,000$ \\
\hline \multirow{2}{*}{ PA5208 } & $\mathrm{D} 70 \pm 6,000$ & $\mathrm{D} 70 \pm 35,000$ \\
\hline & $\mathrm{D} 56 \pm 6,400$ & $\mathrm{D} 56 \pm 30,000$ \\
\hline & $\mathrm{D} 70 \pm 12,800$ & $\mathrm{D} 70 \pm 50,000$ \\
\hline
\end{tabular}

Table 3: Titer determination in checkerboard assay. Legend: Shown are the titer found in the checkerboard assay for chicken and rabbit antibodies.

\begin{tabular}{|c|c|c|c|c|}
\hline \multirow{2}{*}{ Date of receipt } & \multicolumn{2}{|c|}{ Treated } & Untreated (No cuttings) \\
\cline { 2 - 5 } & $\begin{array}{c}\text { Cutting } \\
\text { medium }\end{array}$ & Normal soil & $\begin{array}{c}\text { Cutting } \\
\text { medium }\end{array}$ & $\begin{array}{c}\text { Normal } \\
\text { soil }\end{array}$ \\
\hline $11-3-2013$ (day 0) & $4 \mathrm{~B}, 8 \mathrm{~B}$ & $2 \mathrm{~B}, 6 \mathrm{~B}$ & $12 \mathrm{~B}$ & $10 \mathrm{~B}$ \\
\hline $12-3-2013$ (day 1) & $16 \mathrm{~B}, 20 \mathrm{~B}$ & $14 \mathrm{~B}, 18 \mathrm{~B}$ & $24 \mathrm{~B}$ & $22 \mathrm{~B}$ \\
\hline $14-3-2013$ (day 3) & $28 \mathrm{~B}, 32 \mathrm{~B}$ & $26 \mathrm{~B}, 30 \mathrm{~B}$ & $36 \mathrm{~B}$ & $34 \mathrm{~B}$ \\
\hline $19-3-2013$ (day 8) & $40 \mathrm{~B}, 44 \mathrm{~B}$ & $38 \mathrm{~B}, 42 \mathrm{~B}$ & $48 \mathrm{~B}$ & $46 \mathrm{~B}$ \\
\hline $10-4-2013$ (day 30) & $52 \mathrm{~B}, 56 \mathrm{~B}$ & $50 \mathrm{~B}, 54 \mathrm{~B}$ & $60 \mathrm{~B}$ & $58 \mathrm{~B}$ \\
\hline
\end{tabular}

Table 4: Cutting medium samples. The cutting medium samples, treated and untreated, were collected at the days shown.

\section{Standard curve/working range}

An example of a standard curve in PBS and in blank sample extract is shown in Figure 1A and 1B, respectively. Highest and lowest detection limits and working range were calculated from each standard curve per assay. The lowest detection limit varied from 0.35 to $3.1 \mu \mathrm{g} /$ $\mathrm{ml}$. The highest detection limit varied between 7.8 and $220 \mu \mathrm{g} / \mathrm{ml}$. The working range is the range of concentrations between the lowest and highest detection limit.

\section{Matrix effects}

In order to determine any matrix effects the two standard curves of (Figure 1A and 1B) were compared.

\section{Cross-reactivity}

The compounds tested, i.e., IAA and NBA, showed a cross-reactivity below $1 \%$ in the assay wherein the standards were taken up in PBS from a stock solution in either $\mathrm{MeOH}$ or EtOH (Figure 2A). This means that the antibody was very specific for IBA. However, when the standards were made in $\mathrm{PBS}+5 \% \mathrm{MeOH}$, IAA showed a cross-reactivity of $22 \%$ (Figure 2B). BAP and NAA could not be used in the cross-reactivity assay due to solubility problems.

\section{Linearity}

To determine the linearity in the assay an extract of cutting medium with a relatively high amount of IBA added was serially diluted with blank extract. The results of the analysis are given in Figure 3.

\section{Recovery}

The recovery was determined by adding IBA in a predetermined amount in $\mathrm{MeOH}$ to blank cutting medium samples, followed by extraction and ELISA. The results are given in Table 5. It appeared that performing the extraction twice, the mean recovery was $74.5 \%$.

\section{Sample analysis}

The results of the ELISA of the samples, first extraction and second

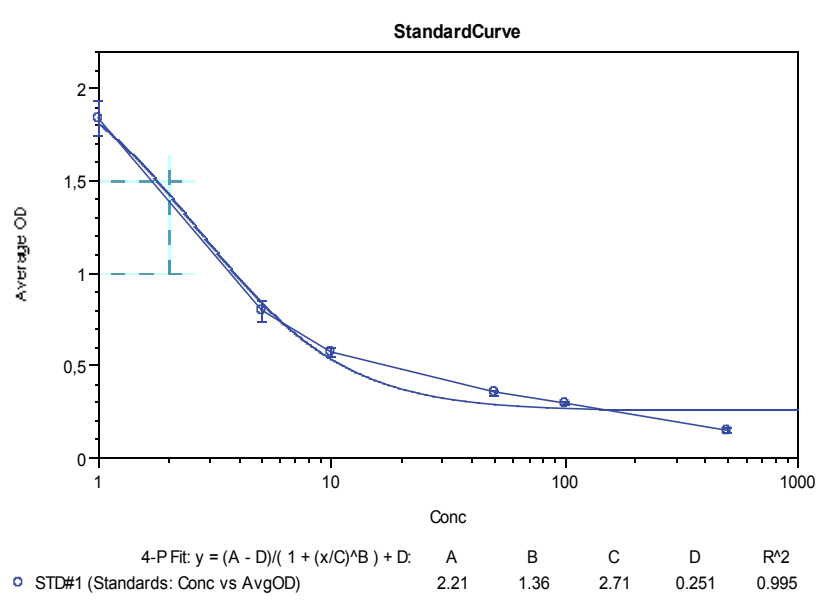

Weighting: Fixed

Figure 1A: Standard curve of IBA in PBS.

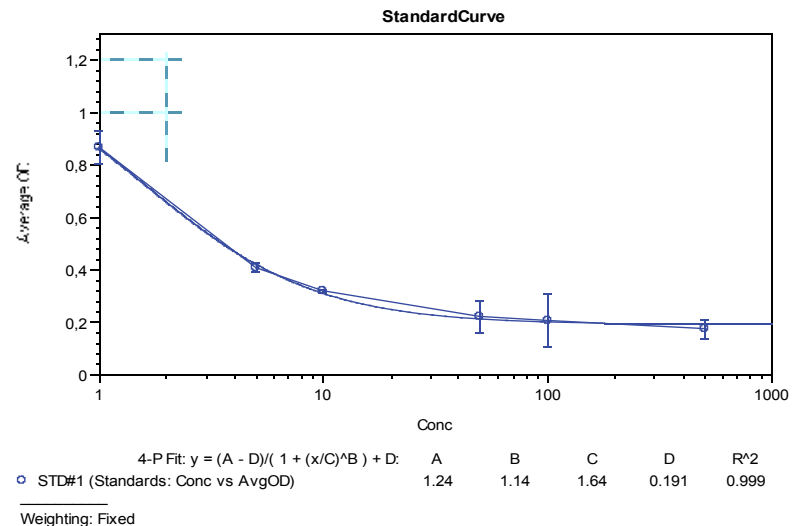

Figure 1B: Standard curve of IBA in cutting medium extract. Figure $1 \mathrm{~A}$ and $1 \mathrm{~B}$ compare the standard curve in assay buffer and extraction medium of blank sample. The respective parameters differ such that a matrix effect has to be concluded

\section{Cross-reactivity}

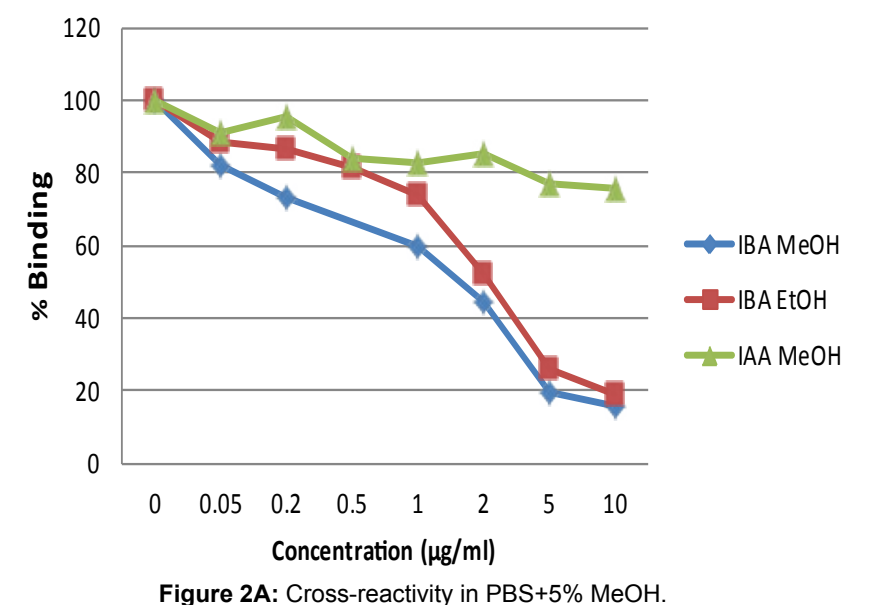




\section{Cross-reactivity}

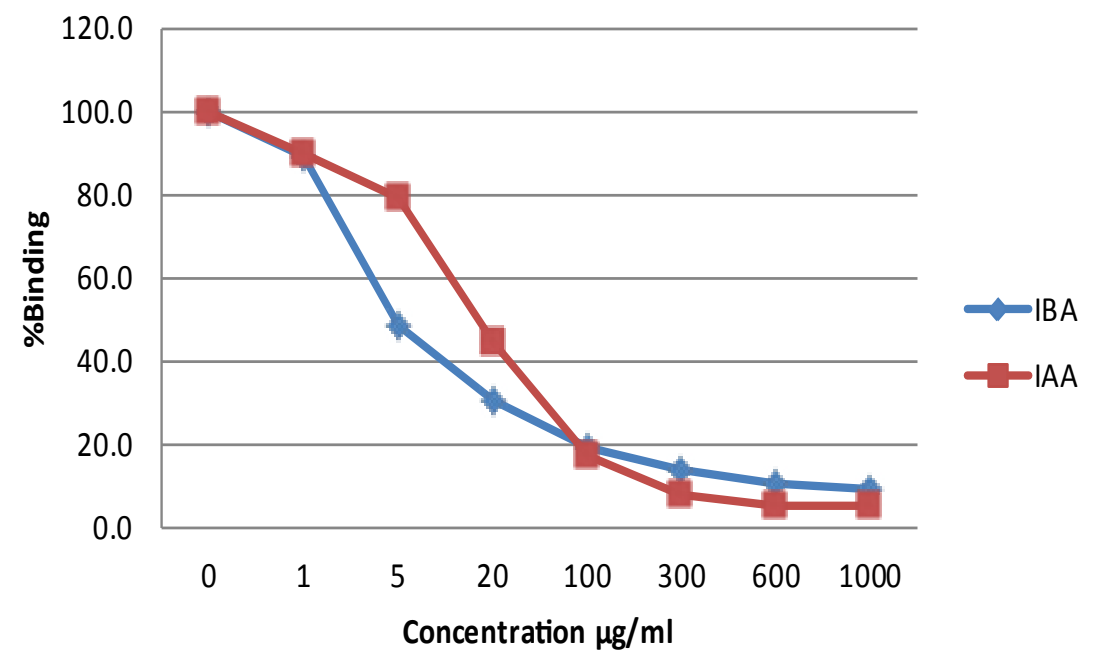

Figure 2B: Cross-reactivity in PBS. The cross-reactivity was determined both in buffer and in buffer $+\mathrm{MeOH}$ or EtOH. In extraction buffer the cross-reactivity of IAA was negligible.

\section{Linearity}

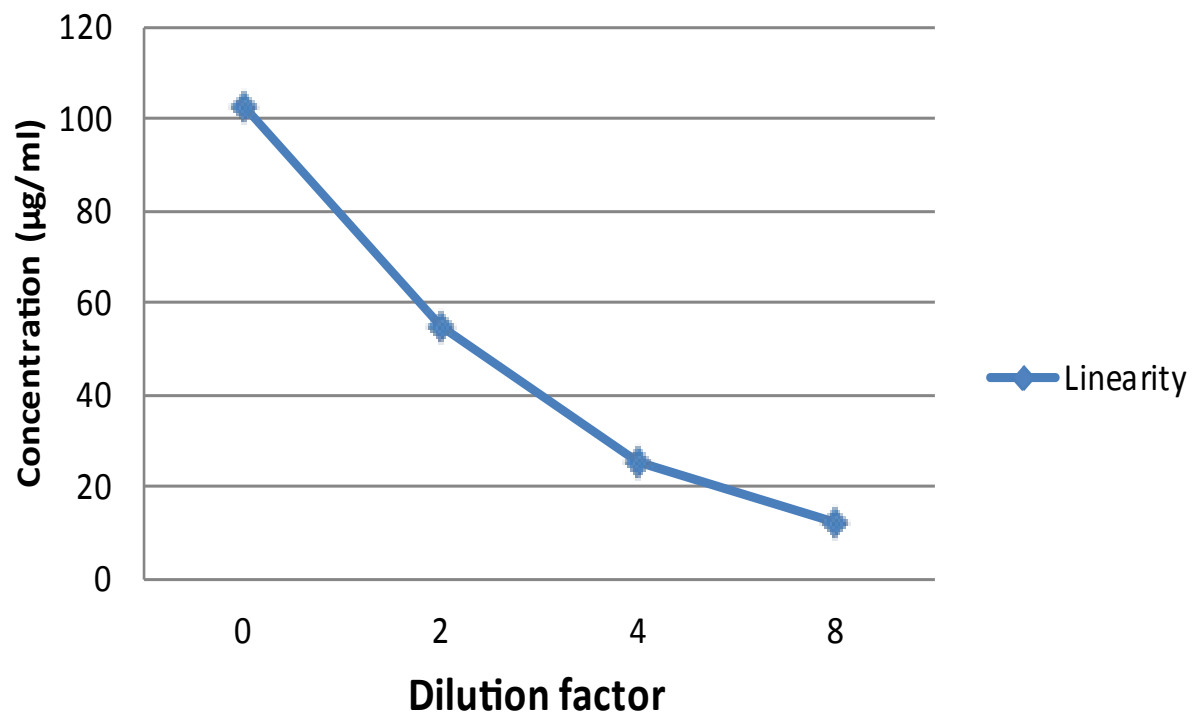

Figure 3: Linearity: Blank sample extract was added with IBA in high concentration and dilutions with assay buffer were measured in the ELISA.

\begin{tabular}{|c|c|c|c|}
\hline Code & Expected $(\mu \mathrm{g})$ & Found $(\mu \mathrm{g} / \mathrm{ml})$ & $\%$ Recovery \\
\hline $\mathrm{S} 1$ & 200 & 152 & 76.0 \\
\hline $\mathrm{S} 2$ & 200 & 154 & 77.0 \\
\hline S3 & 200 & 140 & 70.0 \\
\hline S4 & 200 & 159 & 79.5 \\
\hline S5 & 25 & 17.5 & 70.0 \\
\hline Mean & & & 74.5 \\
\hline
\end{tabular}

Table 5: Recovery of IBA from blank cutting medium. Values of IBA spiked in blank cutting medium. 
Citation: Meulenberg EP (2015) The Development and Application of ELISA for 3-Indole-Butyric Acid. Immunochem Immunopathol 1: 104. doi: 10.4172/2469-9756.1000104

Page 6 of 7

\begin{tabular}{|c|c|c|c|c|c|c|}
\hline Tray code and Date & Cup & Weight (g) & Conc. Extract $1(\mu \mathrm{g} / \mathrm{ml})$ & Conc. Extract $2(\mu \mathrm{g} / \mathrm{ml})$ & Amount of IBA/cup ( $\mu \mathrm{g} \pm \mathrm{SD})$ & IBA Concentration $(\mu \mathrm{g} / \mathrm{g} w w t \pm \mathrm{SD})$ \\
\hline 4B (Day 0) & $E$ & 12.29 & 4.6 & 4.9 & 95 & 7.7 \\
\hline \multirow[t]{5}{*}{$11-3-2013$} & $\mathrm{~F}$ & 14.14 & 3.9 & 3.1 & 70 & 5.0 \\
\hline & G & 13.43 & 5.2 & 3.6 & 88 & 6.6 \\
\hline & $\mathrm{H}$ & 15.06 & 5.1 & 4.0 & 91 & 6.0 \\
\hline & 1 & 12.82 & 3.6 & 2.7 & 63 & 4.9 \\
\hline & $\mathrm{J}$ & 11.77 & 3.7 & 3.1 & 68 & 5.8 \\
\hline Avg & & & 4.4 & 3.6 & $79 \pm 14$ & $6.0 \pm 1.0$ \\
\hline 16B (Day 1) & $\mathrm{O}$ & 16.11 & 2.3 & 1.5 & 38 & 2.4 \\
\hline \multirow[t]{5}{*}{$12-3-2013$} & $\mathrm{P}$ & 18.83 & 4.0 & 2.8 & 68 & 3.6 \\
\hline & Q & 18.43 & 3.6 & 1.7 & 53 & 2.9 \\
\hline & $\mathrm{R}$ & 19.43 & 4.0 & 3.3 & 73 & 3.8 \\
\hline & S & 15.03 & 3.3 & 2.9 & 62 & 4.1 \\
\hline & $T$ & 15.66 & 3.4 & 1.7 & 51 & 3.3 \\
\hline Avg & & & 3.4 & 2.3 & $58 \pm 13$ & $3.3 \pm 0.6$ \\
\hline 28B (Day 3) & $\mathrm{EE}$ & 14.12 & 3.6 & 0.5 & 41 & 2.9 \\
\hline \multirow[t]{5}{*}{$14-3-2013$} & $\mathrm{FF}$ & 15.38 & 3.3 & 1.2 & 45 & 2.9 \\
\hline & GG & 13.83 & 1.8 & 1.0 & 28 & 2.0 \\
\hline & $\mathrm{HH}$ & 13.10 & 1.8 & 1.3 & 31 & 2.3 \\
\hline & II & 12.93 & 2.7 & 0.7 & 34 & 2.6 \\
\hline & $\mathrm{JJ}$ & 9.99 & 1.8 & 1.2 & 30 & 3.0 \\
\hline Avg & & & 2.5 & 1.0 & $35 \pm 7$ & $2.6 \pm 0.4$ \\
\hline 40B (Day 8) & $\mathrm{OO}$ & 13.12 & $<3.6$ & $<2.5$ & & \\
\hline \multirow[t]{5}{*}{$19-3-2013$} & PP & 14.34 & $<3.6$ & $<2.5$ & & \\
\hline & $Q Q$ & 12.34 & $<3.6$ & $<2.5$ & & \\
\hline & $\mathrm{RR}$ & 12.41 & $<3.6$ & $<2.5$ & & \\
\hline & SS & 16.35 & $<3.6$ & $<2.5$ & & \\
\hline & TT & 12.73 & $<3.6$ & $<2.5$ & & \\
\hline Avg & & 13.55 & $<3.6$ & $<2.5$ & $<6.1$ & $<0.45$ \\
\hline 52B (Day 30) & E3 & 11.59 & $<3.1$ & $<1.6$ & & \\
\hline \multirow[t]{5}{*}{$10-4-2013$} & F3 & 15.03 & $<3.1$ & $<1.6$ & & \\
\hline & G3 & 12.26 & $<3.1$ & $<1.6$ & & \\
\hline & $\mathrm{H} 3$ & 12.83 & $<3.1$ & $<1.6$ & & \\
\hline & 13 & 10.94 & $<3.1$ & $<1.6$ & & \\
\hline & J3 & 13.45 & $<3.1$ & $<1.6$ & & \\
\hline Avg & & 12.68 & $<3.1$ & $<1.6$ & $<4.7$ & $<0.37$ \\
\hline
\end{tabular}

Table 6: Concentration of IBA in cutting medium samples from the field trial (ELISA). Shown are the values of IBA in cutting medium at the several sampling points.

extraction, are shown in Table 6. The concentrations found in the first en second extraction were added and back-calculated to the amount of IBA per gram wet weight of cutting medium. The results were not corrected for recovery.

\section{Discussion}

It appeared that the immunization of chickens and rabbits led to the successful production of antibodies against IBA. From the antibodies produced those of rabbit no. PA5208 exhibited the highest titer and were therefore used to design an ELISA. Validation of the ELISA proved that it was useful for the determination of IBA, both in buffer and in extract of growth medium for plant cuttings.

Advantage of the ELISA is that several samples can be assayed in one run. Disadvantage is that for each run a standard curve has to be made and that each assay has its own detection limit and working range.
With regard to the cutting medium samples containing plant cuttings treated with IBA, it was demonstrated that the concentration of IBA decreased in the course of time to reach levels below the detection limit 8 days after treatment. Comparable results were found using an HPLC method for confirmation.

\section{Conclusion}

This is the first mention of an assay for the assessment of IBA in cutting medium. The ELISA described meets all the requirements of a valid assay. Thus it is found to be useful for the determination of IBA in cutting medium. It appeared that IBA was degraded fast and after about 8 days was below the detection limit of the assay. Consequently, the plantlets are allowed to bring on the market according to EU regulations.

\section{References}

1. Meulenberg EP (2012) Antibodies: Applications and new developments, Bentham eBooks. 
Citation: Meulenberg EP (2015) The Development and Application of ELISA for 3-Indole-Butyric Acid. Immunochem Immunopathol 1: 104. doi: 10.4172/2469-9756.1000104

Page 7 of 7

2. Voller A, Bartlett A, Bidwell DE (1978) Enzyme immunoassays with special reference to ELISA techniques. J Clin Pathol 31: 507-520.

3. Wild D (2013) The Immunoassay Hand Book. 4th edn. Theory and applications of ligand binding, ELISA and related techniques, Elsevier. pp: 287-299.
4. Crowther JR (1995) ELISA: Theory and Practice. Methods in Molecular Biology. Trends in Endocrinology \& Metabolism 7: 352-353.

5. Franek M, Hruska K (2005) Antibody based methods for environmental and food analysis: a review. Vet Med-Czech 50: 1-10. 